\title{
Individual factors that cause professional burnout syndrome in social workers, employed in community rehabilitation centre for addictive diseases
}

\author{
Vida Gudzinskiene ${ }^{1, *}$, Andrejus Pozdniakovas ${ }^{1}$, and Jautre Ramute Sinkuniene ${ }^{1}$ \\ ${ }^{1}$ Mykolas Romeris University, Vilnius, Lithuania
}

\begin{abstract}
At the theoretical and empirical levels, the article reveals individual factors that cause professional burnout syndrome in social workers, employed in community rehabilitation centre for addictive diseases. Addiction is considered a disease that has aspects of biological, psychological, social, and spiritual nature. Professional burnout syndrome can be understood from different points of view that in total comprise a general concept and consist of the following aspects: emotional exhaustion, depersonalization, and decrease in self-realization. Research object is individual factors that cause professional burnout syndrome in social workers, employed in community rehabilitation centres for addictive diseases. The aim of the article is to reveal individual factors that cause professional burnout syndrome in social workers, employed in community rehabilitation centre for addictive diseases. Tasks: 1) to provide theoretical assumptions about individual factors that cause professional burnout syndrome; 2) based on experiences of social workers to reveal individual factors that cause professional burnout syndrome in social workers, employed in community rehabilitation centre for addictive diseases. Research methods are academic literature analysis, document analysis, and qualitative research. In the study, semi-structured interviews, quality (content) analysis, summarizing method were used.Empirical research revealed that individual factors that cause the development of professional burnout syndrome in social workers, employed in community rehabilitation centres for addictive diseases, are related to: employees' feelings of inferiority and imposition of excessive requirements on themselves (timidity, self-devaluation; feeling of guilt; lack of self-evaluation skills and imposition of excessive requirements on oneself); personal qualities (too much empathy, attachment to clients or doubts about the meaning of work); individual factors related to the environment (having nobody to talk to about problems, inability to change the environment, prolonged stress, narrowing of interests outside work, and forced abandonment of activities that previously preventively helped to combat professional burnout syndrome). Individual factors related to clients (collapse of hopes to help the client and excessive responsibility of the social worker for the client's life). Participants of the research became "inaccessible" to family members, were unable to distance themselves from work stress (worries outside work, obsessive thoughts that hinder dissociation from work, inability to relax, use of free time for work activities); felt a lack of general and professional competencies.
\end{abstract}

\footnotetext{
*Corresponding author: vida.gudzinskiene@mruni.eu
} 
Key words - community rehabilitation centres for addictive diseases, individual factors, professional burnout, social workers.

\section{Introduction}

Social workers work in a constantly changing social, economic, cultural and political environment, where they are confronted with individuals of different social status, having problem behaviour, complex social issues, and mental disorders [1]. The nature of the work of social workers requires specific skills: to endure the psychological load, to be proactive, empathetic, and persevering, to persevere in the pursuit of the goal, to believe in the significance of one's work, to give all energy to work [2]. The community rehabilitation centre for addictive diseases is a complex organization. The harmful lifestyle of users of psychoactive substances causes many social problems: loss of housing, deteriorating relationships with family members, chaotic behaviour, sometimes, experience in prisons. The person involved in the rehabilitation process needs full social, psychological, and spiritual assistance [3]. Therefore, an interdisciplinary team of specialists plays an important role in the process of client rehabilitation, where social workers are the main specialists who can help people with addiction to reintegrate into society. The quality of team collaboration can determine the motivation of clients participating in a community-based recovery program $[4,5]$. The stress experienced by social workers is usually related to clients' character traits, their weak motivation for change, impulsive behaviour, aggression, and resistance to the recovery program. The high professional requirements set for social workers and stressful working conditions make the preservation of their mental health one of the most acute occupational problems. It should be noted that high workload, internal and external organizational factors, tension and stress, role conflicts, fatigue or exhaustion [6-8], and lack of time planning skills [9] also contribute to the negative well-being of social workers.

Professional burnout is a physical, emotional, and mental exhaustion resulting from longterm involvement in emotionally complex professional situations [10]. Studies that examine factors of professional burnout syndrome in social workers tend to analyse the impact of the work environment on the well-being of employees rather than individual personality traits [11]. Therefore, in order to apply preventive measures to social workers, employed in the community rehabilitation centre for addictive diseases, it is important to actualize individual factors that lead to professional burnout syndrome.

Research problem. After analysing the experiences of social workers, employed in the community rehabilitation centre for addictive diseases, four groups of factors that lead to the development of professional burnout syndrome were identified: individual factors; organizational difficulties at work; interpersonal causes; role conflicts [12]. Due to the limited scope, the following article will discuss only individual factors that cause professional burnout syndrome, the negative consequences of which are manifested in the social environment, family relationships, as well as work communication between colleagues and clients. It is important to reveal individual factors of professional burnout, because only with knowledge can social workers manage the situation or take measures to prevent professional burnout. The research problem can be formulated with the following question: what individual factors lead to professional burnout syndrome in social workers, employed in the community rehabilitation centre for addictive diseases?

Research results and the scientific knowledge gained about individual factors that cause professional burnout syndrome are especially relevant for those social workers, who work tirelessly and in close relationships with clients, trying to help them without recognizing symptoms of professional burnout syndrome and factors that cause it. 
Research object is individual factors that cause professional burnout syndrome in social workers, employed in community rehabilitation centres for addictive diseases.

The aim of the article is to reveal individual factors that cause professional burnout syndrome in social workers, employed in community rehabilitation centre for addictive diseases. Tasks:

1) to provide individual theoretical assumptions related to the development of professional burnout syndrome in social workers;

2) based on experiences of social workers to reveal individual factors that cause professional burnout syndrome in social workers, employed in community rehabilitation centre for addictive diseases.

Research methods: theoretical - analysis of scientific literature and documents; empirical - a semi-structured interview method was used for the collection of data; the content analysis method was used for the analysis of research data. There were 7 social workers, employed in the community rehabilitation centre for addictive diseases, who participated in the research.

\section{Individual factors that cause professional burnout syndrome}

Individual-level professional burnout factors are classified into three main groups: psychological, professional, and socio-demographic [13]. Individual-level psychological features are emotional intelligence, level of neuroticism, opportunities of overcoming anxiety, level of self-esteem, activity motivation related to timidity, self-devaluation and feeling of inferiority, imposition of excessive requirements on oneself, lack of self-evaluation skills, behavioural strategies in stressful situation, extraversion [14]. Individual factors are manifested in the loss of an ideal self-image; loss of illusions; a distinction appears between the conscious and unconscious desires; loss of motivation for searching for existential meaning and disappointment; failed and unfulfilled expectations; insufficient resources to implement strategies to combat burnout syndrome [8]. Researchers note that introverts, pessimists, people with low self-esteem are more likely to experience emotional exhaustion and depression. Psychological protection measures for emotional burnout develop more rapidly in people, who are less sensitive and more emotionally restrained, more stable [15]. Hypersensitivity can completely block the mechanism of psychological defence and prevent it from developing. Moreover, factors such as fear of being rejected, lack of motivation, perfectionism, according to P. Ide [8], are some of the main individual factors contributing to the development of the burnout syndrome. Individual factors can include workaholism, when the workload drains and depletes human strengths and energy, one cannot find balance between work and leisure, family and friends, computer and direct contact with people [16].

Individual-level professional group of factors is comprised of excessive individual, professional, and work or career commitments [17]. Externally, it is a hard-working, ambitious, enthusiastic, empathetic, disciplined employee, who is determined to dedicate oneself to the sole goal - pursuit of success [6]. The pursuit of perfection, strict work discipline, reliability are traditionally considered necessary qualities of a good employee, but in fact, it is a direction aimed not at internal success, but at strict and indisputable compliance with the requirements of the professional environment. Studies have shown that perfectionism positively correlates with the risk of experiencing professional burnout syndrome $[16,6,18]$. Burnout is caused by a disturbed balance between the performance of impeccable professional tasks and maintenance of one's mental health, between individual energy expenditure and the subjective worrying about the significance of one's professional achievements. It should be noted that difficulties in information processing or shorter professional experience also initiate professional burnout [13]. P. Ide [8], analysing professional burnout syndrome, 
claimed that burnout is formed not because a person fully committed oneself, but because one committed oneself incorrectly. People who experience burnout syndrome:

1. Failed to realize that their energy was depleted, that they no longer have sufficient resources, which means that they did not receive enough compared to how much they had given [12];

2. Failed to accept what was given, for example, did not completely notice signs of gratitude sent by other people, and therefore, were suffering from timidity and self-devaluation;

3. Had high expectations of what they will receive, although, in fact, gave nothing themselves, only secretly thought and counted everything they had not been thanked for [8].

At the individual level, socio-demographic characteristics, such as gender, age, number of children, marital status, are important, but researchers have different points of view. For example, some argue [13] that professional burnout is often weaker among those who have started a family, while age is inversely related to the manifestation of professional burnout. The following means that younger employees are more prone to professional burnout. Analogous results were obtained by S. Raižienè and A. Bakšyte [19]; according to the authors, "younger employees, who have not yet mastered certain mechanisms necessary to implement requirements set at work, solve the arising problems, tend to burn out earlier than older ones, who are more mature, stable, are more wise, have an established view of the world" [19]. It should be noted that the importance of age as of a determinant of professional burnout, may vary depending on the work sector and profession. K.V. Katashinskaja [20] notes that age, gender, work experience, and other social, demographic characteristics are not directly related to professional burnout syndrome. More important is the individual response to stressful situations, the feeling that everything is under control can be crucial.

Personal and professional self-realization, job satisfaction, and activity motivation depend on personal values. Values of professional activity of social workers base on the "person-toperson" principles and are manifested in the service for the benefit of others in pursuit of a humane goal, thus common human values become the priority: caring for other people, willingness to communicate and cooperate [21]. Therefore, one of the risk factors for the representatives of the assisting profession to experience professional burnout syndrome are unjustified expectations, intangible results of the work activity [22]. K.V. Katashinskaja [20] claims that the risk of burnout can increase when there are no proper conditions and opportunities for meeting the needs of a person's self-realization, when experiments and innovations are not encouraged, but inhibited. Workers who feel satisfied with the job are less likely to burn out [13]. Creative thinking helps social workers make their daily activities meaningful, flexibly react to changes, stay motivated, see new opportunities in problems, and look at common things from a perspective point of view. A positive approach to work stimulates creative energy of social workers and encourages search for new forms of activity. The research data revealed [23] that creativity of social workers is stimulated by both internal (interest, satisfaction, challenges of the work itself) and external motivation (financial reward, praise and incentives).

In conclusion, professional burnout syndrome is influenced by the very diverse and different categories of individual traits of social workers that interact with each other: hypersensitivity, low self-esteem, pessimism, perfectionism, workaholism. However, there is no consensus on what factors determine the manifestation of the burnout syndrome, because it can be very individual. It is important for social workers, employed in the community rehabilitation centre for addictive diseases, to know and recognize what personal characteristics and individual factors play an important role and influence the course of the professional burnout syndrome. 


\section{Research methodology and subjects}

The qualitative research method was chosen for the study. Given the purpose of the research and the complexity of the topic, data were collected by means of a semi-structured interview. During the semi-structured interview, the researcher anticipates only general questions and is always ready to improvise during the interview [24]. The following approach allowed researchers to be flexible, to adjust questions during the research, ask additional questions for clarification, but general questions ensured that there was no deviation from the topic under consideration. The content of responses to the interview questions was analysed using the method of qualitative content analysis. During the interview, it was asked to answer problematic questions: What personal and institutional aspects lead to a higher probability, risk of professional burnout syndrome, and what are social workers', employed in the community rehabilitation centre for addictive diseases, experiences of professional burnout? The following article analyses only individual factors that cause professional burnout syndrome in social workers, employed in the community rehabilitation centre for addictive diseases.

The sample of the research. We used a criteria-based sample in the study. The informants (social workers) were chosen according to the following criteria: social workers who 1) have a degree in the area of social work; 2) are engaged in social work with persons addicted to psychoactive substances (alcohol, drugs); 3) have no less than 2-year experience related to work with persons addicted to psychoactive substances (addicted to alcohol, drugs); 4) are employed in the community rehabilitation centre for addictive diseases.

The study was conducted in January - March 2020 in the community rehabilitation centre for addictive diseases. 7 social workers participated in the research. Duration of each interview: 50-140 minutes.

The obtained data were analysed by using the content analysis method. The qualitative content analysis was performed in the following sequence [24]: the repeated reading of the content of transcribed interview texts, the distinction of meaning elements in the text analysed, the grouping of the distinguished meaning elements into categories and sub-categories, integration of the categories/sub-categories into the context of the phenomenon analysed and the description of their analysis.

Ethics of the research. Personal permission of the informants to take part in the research was sought. The researchers obliged themselves to the research participants not to divulge the information related to the organisation and the informant. The principles of anonymity, volunteerism, and benevolence were followed [24]. The social workers working with persons addicted to psychoactive substances (alcohol, drugs) were acquainted with the goal of the research, interview questions, and the importance of a reasoned reflection on their experience. Names, surnames, locations, or other similar information that might help recognize research participants and/or identify the subject, were changed. The names of informants were coded (A, B, C...); the following coding breaks the link between research data and the informant who provided the data, in order to maintain anonymity, and for the research results not to harm the informants. The research is presented by interpreting and substantiating theory by information, statements, and quotations obtained during the interview. The quotations of the research participants are authentic, the language was not corrected. Pauses, drawling of vowels and some consonants are marked in the transcription. Meaning of the used characters: $\sim$ pause, ${ }^{*}$ - unfinished word or syllable. 


\section{Individual factors that lead to the development of professional burnout syndrome: Experiences of social workers employed in community rehabilitation centres}

The analysis of the obtained results related to individual factors related to the feeling of inferiority and imposition of excessive requirements on oneself; individual factors related to personal characteristics; individual factors related to the environment; "inaccessibility" to family members; inability to distance oneself from work; lack of competencies; individual factors related to clients (Fig. 1).

The analysis of statements provided by social workers about individual factors that are related to the feeling of inferiority and imposition of excessive requirements on themselves, which in turn lead to the development of professional burnout syndrome, allowed us to distinguish four subcategories: timidity, self-devaluation; self-inflicted accusations; lack of self-evaluation skills and imposition of excessive requirements on oneself. Participants of the research claimed: “... it seems that this one is occupied with some work, another is also doing something, and what can I do, I can't build, I can't putty, in some other works where we are expanding, I can't advise anything, so here it also hit where it hurts $\langle\ldots>$ and whether in general I am able to contribute to anything at all...” (A), “...this kind of selfdoubt..." (C), "Self-esteem was low..." (E). The following self-devaluation and timidity are likely to escalate into self-accusation. Participants of the research emphasized: "... it seems that I do very little... ” (C), “... here I can only blame myself... ” (B), “... feeling of guilt $<\ldots>$ I blamed myself..." (D). It is possible that the following destructive approach as self-accusation, timidity about one's own strengths, manifested in social workers due to lack of self-evaluation skills. Informants indicated: “... incomprehension that I am simply tired...” (D), “... I never tell myself that I may be tired...” (C), “...I didn't think that I need to react to fatigue signals sent by the body..." (F). It is probable that participants of the research, in order to be effective, did not want to accept the idea that they have a limit of their strengths, energy, imposed excessive requirements on themselves. Participants of the research claimed: “...I want to deliver and conduct lectures perfectly..." (C), "... I demanded of myself that I must be in a good mood, always be glad $<\ldots>$; $<\ldots>$ an obsessive thought appeared that I have to be an example $\langle\ldots\rangle$; $<\ldots>$ I couldn't allow myself to be tired..." (D), “... it seemed that work was the only meaningful thing in life, I left all my strengths there $\langle\ldots\rangle$ I had to give up a lot $\langle\ldots\rangle ;\langle\ldots\rangle$ now I think that maybe I wanted to be evaluated..." (F). Following devastating approach towards oneself and work led social workers to emotional exhaustion.

The research revealed that individual factors related to personal characteristics manifest in social workers, employed in community rehabilitation centre for addictive diseases, through: excessive empathy; over-attachment to clients and doubts about the choice of work. Participants of the research mentioned: “... some guy leaves, and it's just. ., <.. > maybe I just overreact inside $\langle\ldots\rangle,\langle\ldots\rangle$ I feel concerned that he left $\langle\ldots\rangle ;\langle\ldots\rangle \ldots$ it is painful when a client leaves ..." (C), “... sometimes you are more worried than the client..." (F), "... when he leaves $\langle\ldots\rangle$ it is difficult..." (A). Social work studies teach that empathy for clients should not go beyond the limit, when social workers worry more than the client oneself, that overly close relationships lead to over-attachment to clients. Participants of the research emphasized: “...I say, well, I will get attached quickly...” (C), “...but at some point I stop calling them clients , or I stop treating them as clients $<\ldots>$ I always wanted, first of all, some kind of a friendly relationship...<..>I sometimes bought them ice-cream...” (D), “... you feel more sympathy, maybe even attachment...” (F). Without controlling sense of empathy and attachment to clients, social workers very quickly become disappointed with relationships, as individuals addicted to psychoactive substances, after 


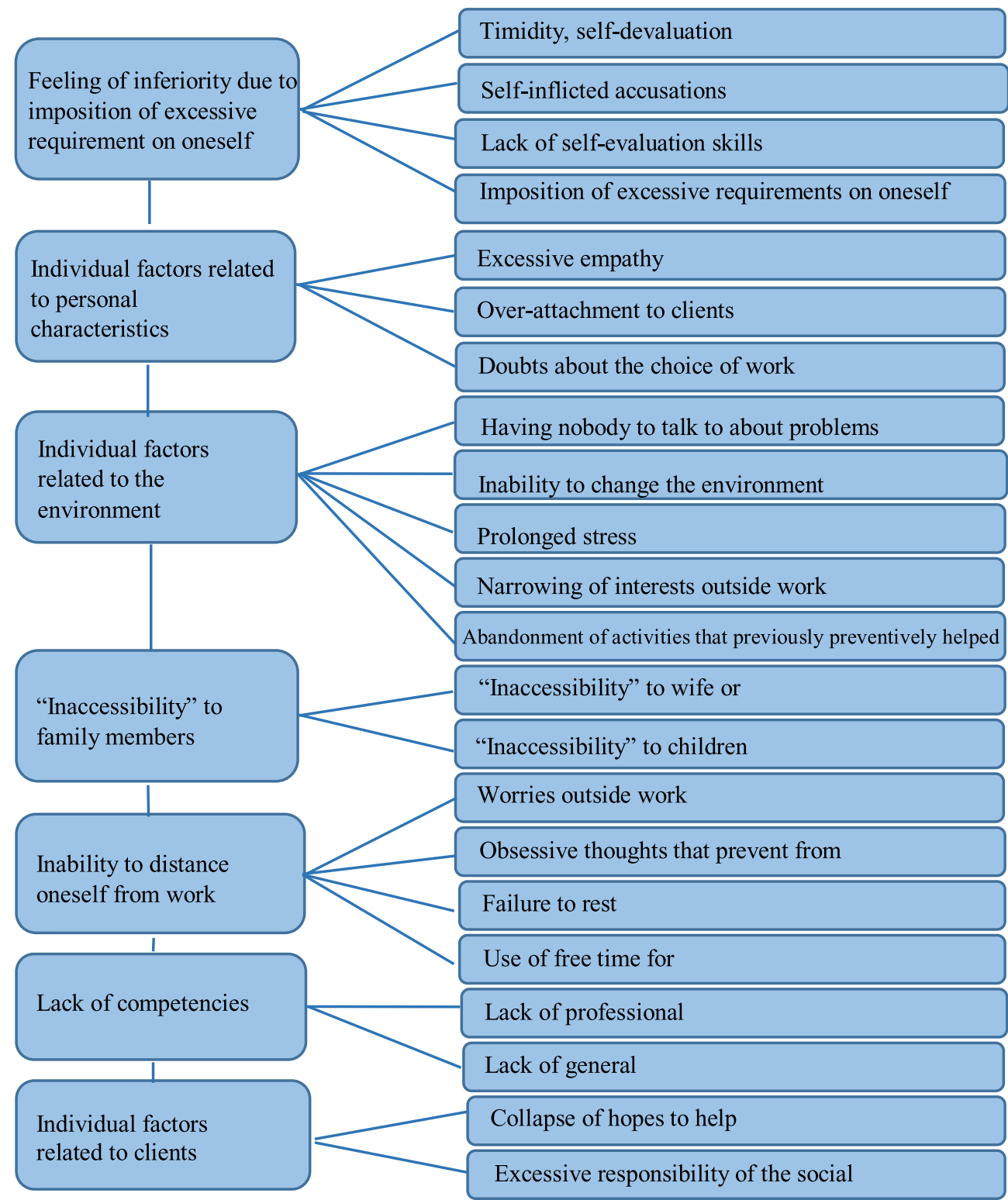

Figure 1. Individual factors related to the development of professional burnout syndrome.

terminating the recovery program, no longer try to communicate and simply forget about such friendships. Due to the experienced disappointment, participants of the research even began doubting what they are doing, began doubting their work: “... what I am generally doing $<\ldots>$; <.. > simply what I am doing here, why I am here, as if I have nothing else to do and realize myself somewhere else..." (C), “... is it worth doing something more here..." (A). The following internal thoughts put pressure on social workers, put their choice of professional activity at doubt. 
The research has shown that social workers also associate individual factors with the environment. The analysis of informants' statements about factors that are related to the environment, which in turn lead to professional burnout, allowed us to distinguish five subcategories: having nobody to talk to about problems; inability to change the environment; prolonged stress; narrowing of interests outside work; forced abandonment of activities that previously preventively helped to combat professional burnout syndrome (Fig. 1). Informants claimed: “... I miss having somebody to pour out to $<\ldots>$ I take everything in from the band, I take in from the employees, I have nowhere to express the accumulated worries. I wish there was some higher chain, so I could give away...; <...> don't find time to let go of all those emotions...” (B), “...don't want to burden others with my problems...” (F). Having nobody to talk to as if "paralyzed" social workers in their own troubles, negative situations. Sharing problems would mean that more than one person would try to solve the problem, the factor of subjective responsibility would disappear, it would be easier to find constructive solutions. Informants stated that they became more passive, it was more difficult to change the environment: “... not going anywhere, constant unchanged environment..." (C), “... I began to isolate myself...” (D). Constant disappointments, internal problems and having nobody to talk to about them, closing off from other people, led to the social workers, employed in the community rehabilitation centre for addictive diseases, being in constant stressful situations. Participants of the research indicated: “. . because you're under constant stress $\langle\ldots\rangle ;\langle\ldots\rangle$ it is stressful when there are unfinished works $\langle\ldots\rangle ;\langle\ldots\rangle$ constant stress, many years of that stress, stress is already accumulated, as before, when I started in " $X$ " (name of the organization), I didn't experience stress at all, and now somehow more burden has arisen, more worries $<\ldots>$ a few stressful days, both at work and at home, then you just can't find time to let go of all those emotions. . " (B), "<.. > simply lasted for weeks $<\ldots>$ ” (D), “... constant stress due to endless problems... ” (F). Prolonged constant stress negatively affects the employee not only in the workplace and work-related areas, but also outside the workplace. Informants noted: "I simply stopped $\langle\ldots\rangle$ doing sports, or cycling, I really used to like that $\langle\ldots\rangle ;\langle\ldots\rangle$ stress affects everything, mood evaporates, desire to go somewhere..." (D), “... I invest everything in work, there is nothing left..." (E), “...you're always not making it in time..." (F). The narrowing of interests outside work meant that for participants of the research work took up more time and more energy, and there remained less energy, time and motivation for recovery. Participants noted that there were situations or circumstances when they had to abandon activities that preventively helped to combat professional burnout: “... I have $<\ldots>$ knee injuries, there is a lot I can't do, I can't play boll, basket, volleyball...” (B), “... I had to give up my hobbies, change my place of residence... " (F), “... business trip $<\ldots>$ time with family are replaced with...” (E). Social workers emphasized that they had to abandon their favourite activities, which potentially negatively affected not only work efficiency, but also the quality of private life.

Participants of the research mentioned that they were "inaccessible" to family members, wife or girlfriend, as well as children. Participants claimed: “. . at home $<\ldots>$ wife, calls, "I'm tired, come... ” (B), “... I stopped loving myself, how can I qive some kind of love..." (D), “...physically at home, but my thoughts were in solving endless questions..." (F). Social workers indicated that they were no longer able to pay enough attention and love to their family members and loved ones. Informants noticed: “. . you want to spend more time with the child, but you have to sit at the computer and work in the evenings..." (F). Accordingly, social workers, employed in the community rehabilitation centre for addictive diseases, out of great desire to help others hurt their loved ones by devoting less time to them. Without experiencing positive emotions, participants of the research deteriorated the quality of their life, because positive emotions maintain good mental health [25]. 
Having analysed statements of social workers, employed in community rehabilitation centres for addictive diseases, about the inability to distance themselves from work, four subcategories were distinguished: worries outside work; obsessive thoughts that prevent one from distancing from work; failure to rest; use of free time for work activities (Fig. 1). Participants of the research claimed: “... problems began to accumulate not only in the rehabilitation centre, but also outside it. Everything accumulated, accumulated inside, problems appeared simply everywhere, wherever I'd go...” (D), “...don't want to go to work and bring along some kind of problems..." (C). Problems outside work prevented from finding some meaningful activities that would help to distance oneself from work matters. As a result, informants claimed that it was becoming more and more difficult to dispose of obsessive thoughts: “... but I also constantly feel tension $~ 24$ hours a day. I lie down and I get up with the same thought $<\ldots>$ ” (C), “...I was tired of my negative thoughts $<\ldots>$ the brain couldn't turn off $<\ldots>$ a lot of negative thoughts that are impossible to get rid of...” (D), “... sometimes obsessive thoughts...” (F). The following state prevented social workers, employed in the community rehabilitation centre for addictive disease, from relaxing even during free time. Participants of the research noticed: “...I am sitting, I need to go and do something, but I can't $\langle\ldots\rangle$; $\langle\ldots\rangle$ not being able to rest $\langle\ldots\rangle$ I have to do something all the time $\langle\ldots\rangle ;\langle\ldots\rangle$ I realized that I can't rest completely” (B), “...I have to work, I can't lie around...” (C), “... you lie, there's that anxiety that you need to work..." (F). It should be noted that rest is necessary and indispensable for workers to further continue to carry a high load of communication and cooperation, but failure to rest and use of free time for work activities prevented them from regaining strengths. Informants claimed: "During Christmas, on December 25, there were like 6 calls $\langle\ldots\rangle$; $\langle\ldots\rangle$ when someone cries on the cell, it's hard to hang up (the receiver) $<\ldots>$ I don't know how long professional activity lasts” (B), “... there was a time, when all days were the same for me, be it Monday, be it Sunday... ” (C), “... as if you're at work for 24 hours... ” (A). For social workers, qualitative time is the main way to prevent the development of professional burnout, lack of leisure has the opposite effect and leads to professional burnout, because work-related stress interferes with people's understanding, cognition, motivation, and emotions [26]. Chronic stress can lead to wandering of thoughts (i.e. distraction, lack of concentration), because stressors deplete psychological and physiological resources that are needed in order to focus. It can be assumed that people use wandering of mind as a mean to escape from the present moment, not to think about the difficult reality and not to give in to emotions, but the following state can lead to suffering. Moreover, the immune system is weakened [27]. People are unwell and doctors cannot find any medical reasons [28].

Research participants claimed that while carrying out social work in community rehabilitation centre for addictive diseases, they felt a lack of professional and general competencies (Fig. 1). Informants claimed: “... willingness to do the work and lack of knowledge of the specifics $\langle\ldots\rangle$, no practical training to do that thing $\langle\ldots\rangle$; $\langle\ldots\rangle$ lack of competence in that field...” (C), “... in the beginning a lot of mistakes had to be made $<\ldots .>$ it was necessary to learn everything $\langle\ldots>$ I didn't know what to say, how to say $<\ldots>$ ” (D), “... a bunch of questions related to the centre's methodology that are not taught during studies $<\ldots>$ time was needed" $(\mathrm{F})$. The reality is that there were no specific studies on how to work in a community rehabilitation centre for addictive diseases; thus, social workers working with individuals addicted to psychoactive substances had to take independent interest and participate in trainings. Some of them mentioned that they lacked transferable skills: “... simply with a computer..." (C), “... to create some tables, how to do all of that, I in general*, why me...” (D). Lack of general competencies was not a major problem, but work efficiency is declining, because additional time is needed for learning computer literacy during work. 
The analysis of individual factors, which lead to the development of professional burnout syndrome in social workers, employed in the community rehabilitation centre for addictive diseases, allowed to distinguish two subcategories: collapse of hopes to help the client and excessive responsibility of the social worker for the client's life. Research participants emphasized: “... your efforts, your hopes go nowhere, you put hopes in the person, when you believe in one and see that he turns away and waves his hand..." (A), "... you led that person, $\sim$ put some hopes in one $\sim$ and you know, one stands, and leaves, you are still worried...” (B), “...especially when one leaves in half a year $<\ldots>$ as if something was ripped from you..." (F). Social workers painfully reacted to the termination of the recovery program by clients; therefore, excessive hopes and expectations for the client led to: “...it seems a lot has been done to stop that person” (A), “... automatically become co-dependent $\langle\ldots\rangle$ I thought that if right words were found to encourage, the person will stay $<\ldots\rangle$; $<\ldots>$ there were times when I wanted to decide for them..." (D), "... sometimes out of inertia that you want more than one..." (E). Social workers often have to confront themselves, because excessive responsibility for the client's life persecutes them as a professional disease and exhausts social workers, who take too much responsibility for the life of another person.

\section{Conclusions}

It is important for a social worker, employed in the community rehabilitation centre for addictive diseases, to understand and recognize what personal characteristics influence the course of the professional burnout syndrome. On the theoretical level, most researchers agree that professional burnout is caused by the following individual factors: imposition of excessive requirements on oneself, failed and unfulfilled and expectations, loss of existential meaning and motivation, inability to draw the line between work and private life, or simply "immersion" in work and abandonment of private life.

Empirical research on the experiences of social workers, employed in the community rehabilitation centre for addictive diseases, revealed the following individual factors that cause the development of the professional burnout syndrome:

- factors related to the feeling of inferiority and imposition of excessive requirements on oneself - timidity about one's abilities and self-devaluation, lack of self-evaluation skills, selfinflicted accusations due to uncertainty of performance; perfectionist approach to work;

- factors related to the personal characteristics of a social worker - excessive empathy and over-attachment to clients, negative emotions due to their disappointing behaviour; social workers' doubts about the right choice of work;

- factors related to the environment - having nobody to talk to about problems, stressful work environment, narrowing of interests outside work, forced abandonment of activities that previously preventively helped to combat professional burnout syndrome;

- factors related to the inability to distance oneself from work - obsessive thoughts, inability to properly balance work and rest time, use of free time for work activities, inability to pay enough attention and love to family members and close people;

- factors related to the lack of professional and general competencies - lack of knowledge about the methods and specifics of work in the community rehabilitation centre for addictive diseases, peculiarities of clients, inability to reflect on experience, lack of time to engage in self-education;

- factors related to clients - collapse of hopes to help the client, excessive responsibility for the client's life, disappointment with the results of work and loss of meaning.

It is expedient for social workers, employed in the community rehabilitation centre for addictive diseases, to apply various preventative and professional burnout overcoming measures in personal activities: self-education in developing self-evaluation skills; communicate and 
collaborate with colleagues; take care of oneself by qualitatively spending time with family members and friend. Moreover, it is expedient to take the initiative, take an independent interest, and participate in the organized qualification improvement trainings to improve professional skills of social work. It is important to acquire more knowledge about peculiarities of addictive diseases and the specifics of working with addicts. The same refers to application of interventions in the process of psychosocial rehabilitation; manifestations of professional burnout in social work and overcoming strategies; ways of helping oneself to overcome emotional stress; team work, conflict and stress management.

The heads of rehabilitation institutions for addictive diseases are recommended to pay more attention to the organization of theoretical, practical seminars and practical trainings for the professional qualification improvement of social workers, and especially to the supervision of implementation. The heads are encouraged to develop strategies for overcoming professional burnout syndrome by developing social workers' self-evaluation and reflection skills, teaching to look at difficult situations globally, drawing positive experiences from colleagues by reflecting, enabling the use of creative and innovative social work tools.

\section{References}

[1] C. Marc, C. Osvat. Stress and Burnout among Social Workers: Social Work Review / Revista de Asistenta Sociala 12(3), 121-130 (2013). Retrieved from http://search.ebscohost.com.skaitykla.mruni.eu/login.aspx?direct=true\&db=sih\&AN= 90392584\&site $=$ ehost-live

[2] V. Gudžinskienè, J. Norvaišaitè. Socialinio Darbuotojo Kompetencijų Sampratụ Analizè. Social Education / Socialinis Ugdymas 11(22), 55-64 (2010). Retrieved from http://search.ebscohost.com.skaitykla.mruni.eu/login.aspx?direct $=$ true $\& d b=\operatorname{sih} \& A N=$ $52489375 \&$ site $=$ ehost-live

[3] Drug, Tobacco and Alcohol Control Department. Annual 2016 report, Vilnius (2016). Retrieved from https://ntakd.lrv.lt/uploads/ntakd/documents/files/34862\% 20NTAKD\%20Metinis\%20prane\%C5\%A1imas(1).pdf

[4] S. Mačiulaitienè. Reabilitacinès bendruomenès ir joje taikomo gydymo modelio bei priklausomybès ligomis sergančiụ asmenụ santykis (doctoral thesis, Vytautas Magnus University) (2012). Retrieved from https://vb.vdu.lt/object/elaba:1918656/

[5] K. Sroda. Asmenų, dirbančiụ priklausomybès ligụ centruose, darbo pobūdžio ir požiūrio i pacienta vertinimas (doctoral thesis, Vilnius University) (2016)

[6] Т. I. Ronginskaja (Т. И. Ронгинская). Специфика синдрома выгорания в профессиях с высоким уровнем стресса. Вестник Санкт-Петербургского университета. Серия 16. Психология Педагогика (2) (2016) Retrieved from https://cyberleninka.ru/article/n/ spetsifika-sindroma-vygoraniya-v-professiyah-s-vysokim-urovnem-stressa

[7] V. M. Fomina (B. М. Фомина). Эмоциональное выгорание у социальных работников и специалистов по социальной работе: факторы риска и специфика (на материалах ЗАТО Северск Томской области): магистерская диссертация по направлению подготовки: 39.04. 02- Социальная работа (2017). Retrieved from file://C:/Users/ Andrius/Downloads/\%D0\%92\%D0\%A0.pdf.pdf

[8] P. Ide. Perdegimo sindromas gebejjimo duoti liga: Suprasti, pripažinti, gydyti. Vilnius: VšI "Magnificat leidiniai" (2018)

[9] V. Gudžinskienè. Socialinių darbuotojụ, dirbančių vaikų globos namuose, laiko vadyba kaip perdegimo sindromo prevencija. Societal Innovations for Global Growth 1(1), 976-985 (2012) 
[10] P. McFadden, A. Campbell, \& B. Taylor. Resilience and burnout in child protection social work: Individual and organisational themes from a systematic literature review. The British Journal of Social Work 45(5), 1546-1563 (2015)

[11] M.A. Wagaman, J.M. Geiger, C. Shockley \& E.A. Segal. The role of empathy in burnout, compassion satisfaction, and secondary traumatic stress among social workers. Social work 60(3), 201-209 (2015). Retrieved from https://academic.oup.com/sw/article-abstract/60/3/201/2280639

[12] V. Gudžinskienè, \& A. Pozdniakovas. Socialiniụ darbuotojụ, dirbančiu priklausomybès ligụ reabilitacijos bendruomeneje, profesinio perdegimo sindromo raiška (2020). Retrieved from https://repository.mruni.eu/bitstream/handle/007/17036/6239-14966-1PB.pdf? sequence $=1 \&$ isAllowed $=\mathrm{y}$

[13] L. Pradas-Hernandez, T. Ariza, J.L. Gomez-Urquiza, L. Albendin-Garcia, E. De la Fuente, \& G.A. Candas-De la Fuente. Prevalence of burnout in paediatric nurses: a systematic review and meta-analysis. PLoS ONE 13(4), 1-14 (2018)

[14] M. Iorga, V. Socolov, D. Muraru, C. Dirtu, C. Soponaru, C. Ilea, \& D.G. Socolov. Factors influencing burnout syndrome in obstetrics and gynecology physicians. BioMed Research International 1-10 (2017)

[15] N.A. Ognerubov, \& M.A. Ognerubova (Н.А. Огнерубов и М.А. Огнерубова) Синдром эмоционального выгорания у врачей-терапевтов. Вестник Тамбовского университета. Серия: Естественные и технические науки 20(2) (2015). Retrieved from file://C:/Users/Andrius/Downloads/sindrom-emotsionalnogo-vygoraniyau-vrachey-terapevtov.pdf

[16] J.P. Platonov (Платонов, Ю. П.). Факторы, обусловливающие профессиональное выгорание (2012). Retrieved from http://www.elitarium.ru/faktory_professionalnoe_ vygoranie/

[17] R. Vimantaitè, \& A. Šeškevičius. Perdegimo sindromas tarp Lietuvos kardiochirurgijos centruose dirbančiụ slaugytojụ. Medicina, 42(7), 600-605 (2006)

[18] J. Navaitienè, V. Danilovienè. Mokytoju perdegimas darbe ir perfekcionizmas. Ugdymo psichologija (2017). Retrieved from http://web.a.ebscohost.com.skaitykla.mruni.eu/ ehost/pdfviewer/pdfviewer?vid=4\&sid=56be3a1d-b369-4eca-bbfa-23eb33837c9f\% 40sdc-v-sessmgr01

[19] S. Raižienè, \& A. Bakšytè. Socialines paslaugas teikiančių darbuotojụ perdegimo sindromo, socialinès paramos bei saviveiksmingumo sạsajos. Socialinis darbas, 9(2), 119126, (2010)

[20] K.V. Katashinskaja (К.В. Каташинская). Факторы, влияющие на развитие синдрома профессионального выгорания у специалистов по социальной работе (2015). Retrieved from https://scienceforum.ru/2015/article/2015014875

[21] L.V. Surzhenko, \& V.A. Lugovskij (Л.В. Сурженко и В.А. Луговский. Ценности личности как фактор формирования синдрома психического выгорания у преподавателей высшей школы. Политематический сетевой электронный научный журнал Кубанского государственного аграрного университета (88), (2013). Retrieved from https://cyberleninka.ru/article/n/tsennosti-lichnosti-kak-faktorformirovaniya-sindroma-psihicheskogo-vygoraniya-u-prepodavateley-vysshey-shkoly

[22] S.N. Koloncova, \& S.V. Berezin (С.Н. Колонцова, и С.В. Березин) Влияние негативных факторов профессиональной деятельности на поведение человека и их профилактика. Молодой исследователь: вызовы и перспективы 11 (2018). Retrieved from https://internauka.org/archive2/moluch/33(86).pdf\#page=12 
[23] J.R. Šinkūnienè. Kūrybiškumo aspektai socialiniame darbe (Aspects of creativity in social work). Socialinis darbas, 2011 10(1), 63-70, Mykolas Romeris University (2011)

[24] J.W. Creswell. Steps in conducting a scholarly mixed methods study (2013)

[25] G.N. Rackoff, \& M.G. Newman. Reduced positive affect on days with stress exposure predicts depression, anxiety disorders, and low trait positive affect 7 years later. Journal of Abnormal Psychology 129(8), 799 (2020)

[26] J. Siegrist, \& M. Wahrendorf. Failed social reciprocity beyond the work role. Work Stress and Health in a Globalized Economy (pp. 275-291), Springer, Cham (2016)

[27] A.A. Prather. Sleep, stress, and immunity. Sleep and Health (pp. 319-330), Academic Press (2019)

[28] R. Mishra. Welfare state capitalist society 5, Routledge (2014) 